\title{
STUDI PERHITUNGAN RELAY JARAK PADA SALURAN DOUBLE CIRCUIT DENGAN SINGLE CONDUCTOR ANTARA GI KAPAL - GI PEMECUTAN KELOD MENGGUNAKAN ARTIFICIAL NEURAL NETWORK (ANN)
}

\author{
Alfian Budy Hadianto ${ }^{1}$, I Gede Dyana Arjana ${ }^{2,}$ Widyadi Setiawan ${ }^{3}$
}

\begin{abstract}
The use of distance relays in the system SUTT $150 \mathrm{kV}$ network, is expected to help the reliability of the transmission system. Setting the value of the distance relay network systems SUTT 150 kV GI Kapal - GI Pemecutan kelod specified by PLN, to do research to obtain the new distance relay settings. Value setting relays within the network system SUTT 150 kV GI Kapal - GI Pemecutan kelod: Zone 1: $(R=0.977, X=$ 2.684, $Z=2.86)$, Zone 2: $(R=1.341, X=3684, Z=3.92)$, zone 3 : $(R=2,107, X=5789, Z=6.16)$. Methods used to determine the return value of the distance relay settings for securing network systems SUTT $150 \mathrm{kV}$ GI Kapal - GI Pemecutan kelod is a method of Artificial Neural Network. Application of the method backpropagation Artificial Neural Network is used to determine the value of setting relays within the network system SUTT 150 kV GI Kapal - GI Pemecutan kelod obtained from the method of Artificial Neural Network is zone $1(R=0.9911, X=2.6886, Z=$ 2.86), zone 2: $(R=1.3313, X=3.6798, Z=3.92)$, zone 3 : $(R=$ 2.1251, $X=2.0995, Z=6.16)$. Percentage difference ie, zone $1(R$ $=0.0144 \%, X=0.0017 \%, Z=0.0000 \%)$, Zone $2:(R=0.3626 \%$, $X=0.3710 \%, Z=0.3706 \%)$, Zone 3: $(R=1.1751 \%, X=$ $1.1562 \%, Z=1.1538 \%$ ).
\end{abstract}

Keywords- Distance relay, short circuit, Artificial Neural Network, distance relay setting.

Intisari- Penggunaan rele jarak pada sistem jaringan SUTT $150 \mathrm{kV}$, diharapkan dapat membantu keandalan dari sistem transmisi. Nilai setting rele jarak pada sistem jaringan SUTT 150 kV GI Kapal-GI Pemecutan kelod yang sudah ditentukan oleh PLN, akan dilakukan penelitian untuk mendapatkan setting rele jarak yang baru. Nilai setting rele jarak pada sistem jaringan SUTT 150 kV GI Kapal-GI Pemecutan kelod: zona 1: $(R=0.977, X=2.684, Z=2.86)$, zona 2: $(R=1.341$, $X=3.684, Z=3.92)$, zona 3: $(R=2.107, X=5.789, Z=6.16)$. Metode yang dipergunakan untuk menentukan kembali nilai setting rele jarak untuk mengamankan sistem jaringan SUTT 150 kV GI Kapal-GI Pemecutan kelod adalah metode Artificial Neural Network. Penerapan metode backpropagation Artificial Neural Network digunakan untuk menentukan nilai setting rele jarak pada sistem jaringan SUTT 150 kV GI Kapal-GI Pemecutan kelod yang didapatkan dari metode Artificial Neural Network

\footnotetext{
${ }^{1}$ Mahasiswa, Jurusan Teknik Elektro dan Komputer Fakultas Teknik Universitas Udayana, Jln. Kampus Bukit Jimbaran, Badung, Bali. 80361, Tel. 08174785328; Email: alfianhadianto278@gmail.com

2,3 Dosen Jurusan Teknik Elektro dan Komputer Fakultas Teknik Universitas Udayana, Jln. Kampus Bukit Jimbaran, Badung Bali. 80361, Tel. 0361703315 fax: 0361703315. Email :

22dyanaarjana@ee.unud.ac.id, ${ }^{3}$ widyadi@unud.ac.id,
}

adalah zona 1: $(R=0.9911, X=2.6886, Z=2.86)$, zona 2: $(R=1.3313$, $X=3.6798, \quad Z=3.92)$, zona 3: $(R=2.1251, \quad X=2.0995, Z=6.16)$. Persentase perbedaannya yaitu, zona 1: $(R=0.0144 \%$, $X=0.0017 \%, Z=0.0000 \%)$, zona 2: $(R=0.3626 \%, X=0.3710 \%$, $Z=0.3706 \%)$, zona 3: $(R=1.1751 \%, X=1.1562 \%, Z=1.1538 \%)$.

Kata Kunci- Rele jarak, gangguan hubung singkat, Artificial Neural Network, setting rele jarak.

\section{Pendahuluan}

Proteksi sistem tenaga mempunyai peran yang sangat penting terbentang pada jarak yang jauh melalui daerah dengan bermacam kondisi cuaca dan tanah. Untuk menangani berbagai gangguan yang terjadi maka sistem proteksi ini diharapkan, andal, cepat selektif, dan gangguan yang terjadi pada sistem tenaga adalah saluran transmisi dalam pada saluran transmisi. sasaran utama dari kebanyakan yang merupakan saluran penghubung antara pembangkit dan pusat beban yang sensitif. Rele jarak (distance relay) adalah salah satu sistem proteksi yang digunakan pada jaringan transmisi [1]. Sistem proteksi rele jarak pada Saluran Udara Tegangan Tinggi $150 \mathrm{kV}$ (SUTT $150 \mathrm{kV}$ ) dikelompokkan dengan beberapa zona (zone), diantaranya Zona1, Zona2, dan Zona3. Pengaruh mutual impedansi (mutual impedance) adalah salah satu aspek teknis yang mempengaruhi jangkauan pengamanan rele jarak (distance relay) pada SUTT sirkit ganda (double circuit) [2].

Beberapa penelitian yang telah dilakukan sebelumnya terkait rele jarak tersebut antara lain“Analisis Setting Rele Jarak Pada Sistem SUTT 150 kV Pembangkit Celukan Bawang" oleh Bhimantara Ari Sugandi (2010) dengan metode analisis perhitungan, "Setting Rele Jarak Pada Sistem SUTT 150 kV GI Kapal - GI Padang Sambian Menggunakan Metode Adaptive Neuro - Fuzzy Inference System (ANFIS)" oleh M. Nordiansyah (2014) dengan metode ANFIS dan "Comparative Evaluation of Adaptive and Conventional Distance Relay for Parallel Transmission Line with Mutual Coupling" oleh S.G. Srivani, Chandrasekhar Reddy Atla, dan K.P. Vittal (2008) dengan metode simulasi pada PSCAD / EMTDC digunakan sebagai acuan (referensi) dalam pengembangan pembahasan pada usulan penelitian ini. Hal ini bertujuan untuk menemukan batasan - batasan masalah yang akan dibahas pada penelitian ini. Penelitian ini membahas tentang evaluasi perbandingan adaptif rele jarak dengan konvensional rele jarak pada jaringan transmisi 
dengan memperhitungkan mutual coupling.

\section{RELE JARAK}

Rele proteksi adalah suatu komponen dalam sistem pengaman saluran transmisi, yang digunakan untuk mengamankan transmisi tenaga listrik. Proses kerja dari rele jarak adalah ketika terdapat gangguan pada transmisi, maka peralatan sensing pada rele bekerja mendeteksi adanya gangguan tersebut dan selanjutnya sinyal dikirim menuju circuit breaker (pemutus) untuk memutuskan transmisi yang mengalami gangguan [3]. Berikut dijelaskan mengenai prinsip kerja rele jarak:

- Rele jarak digunakan untuk mengukur tegangan pada titik rele dan arus gangguan, dengan cara membagi besaran tegangan dan arus. Sehingga perhitungan impedansinya ditentukan dengan persamaan berikut ini[4].

$Z_{f}=V_{f} / I_{f}$

dimana $Z_{f}=\operatorname{Impedansi}(\Omega), V_{f}=$ Tegangan $(\mathrm{V}), I_{f}=$ Arus gangguan (A)

\section{Setting Rele Jarak}

Menetapkan terlebih dahulu nilai dari impedansi di sistem tenaga primer. Sehingga impedansi sekunder dapat dihitung dengan persamaan berikut ini [5]

$$
Z_{s}=Z_{p} x\left(\frac{C T_{\text {ratio }}}{P T_{\text {ratio }}}\right)
$$

dimana, $Z_{s}=$ Impedansi sekunder $(\Omega), Z_{p}=$ Impedansi primer $(\Omega), C T_{\text {ratio }}=$ Rasio Transformator Arus (A), $P T_{\text {ratio }}=$ Rasio Transformator Tegangan (V)

\section{Mutual Induktansi}

Induktansi merupakan sifat suatu rangkaian listrik yang dapat menyebabkan timbulnya gaya gerak listrik di dalam rangkaian yang mengakibatkan perubahan arus yang melewati rangkaian tersebut (self inductance) atau akibat perubahan arus yang melewati rangkaian lainnya induktansi bersama (mutual inductance) [6]

3. Geometric Mean Radius (GMR) dan Geometric Mean Distance (GMD)

Pada saluran transmisi double circuit, induktansi juga dipengaruhi oleh Geometric Mean Radius (GMR) dan Geometric Mean Distance (GMD) [7]. Berikut ini persamaan GMD dan GMR [8].

$$
\begin{aligned}
& G M D=\left(D_{A B e q} D_{B C e q} D_{A C e q}\right)^{1 / 3} \\
& D_{A B e q}=\left(D_{12} D_{1^{\prime} 2}, D_{12^{\prime}}, D_{1^{\prime} 2}\right)^{1 / 4} \\
& D_{B C e q}=\left(D_{23} D_{2^{\prime} 3^{\prime}}, D_{23^{\prime}}, D_{2^{\prime} 3}\right)^{1 / 4} \\
& D_{\text {ACeq }}=\left(D_{13} D_{1^{\prime} 3^{\prime}} D_{13}, D_{1^{\prime} 3}\right)^{1 / 4}
\end{aligned}
$$

dimana, GMD = Geometric Mean Distance, Deq = Jarak yang diukur dari titik pusat penghantar (m).

\section{Impedansi Saluran Transmisi}

Impedansi adalah parameter pokok yang digunakan pada perhitungan setting rele jarak. Impedansi pada saluran transmisi terdiri dari impedansi urutan nol, impedansi urutan positif dan impedansi urutan negatif. Persamaan impedansi dapat dilihat sebagai berikut [5].

$$
\mathrm{Z}=\mathrm{R}+\mathrm{j}\left(\mathrm{X}_{\mathrm{L}}+\mathrm{X}_{\mathrm{C}}\right)
$$

dengan , $\mathrm{Z}=$ Impedansi $(\Omega), \mathrm{R}=$ Resistansi $(\Omega), \mathrm{X}_{\mathrm{L}}=$ Reaktansi induktif $(\Omega), \mathrm{X}_{\mathrm{C}}=$ Reaktansi kapasitif $(\Omega)$

- Artificial Neural Network merupakan proses pembelajaran yang terjadi pada otak manusia yang dibuat manusia untuk menstimulasikannya. Syaraf tiruan yang bertujuan untuk menyelesaikan proses pehitungan dan penyimpanan informasi yang diberikan selama proses pembelajaran dengan mengimplementasikannya menggunakan peralatan bantu berupa komputer. Jaringan syaraf tiruan terdiri dari beberapa neuron yang berhubungan bobot yaitu setiap informasi yang diterima neuron akan ditransformasikan melalui jaringan keluarannya ke neuron yang lain. Input diproses oleh suatu fungsi perambatan yang akan menggabungkan nilai semua bobot yang datang. Hasil penggabungan ini kemudian dibandingkan dengan nilai ambang (thershold) melalui fungsi aktivasi neuron. Nilai input yang melewati nilai threshold maka neuron diaktifkan dan neuron tersebut akan mengirimkan nilai output melalui bobotbobot output ke semua neuron yang terhubung,dan demikian seterusnya.

\section{Proses Pembelajaran Artificial Neural Network}

Artificial Neural Network memiliki struktur yang tidak dapat diubah. Jaringan ini terdiri dari sejumlah neuron dan memiliki nilai tertentu yang menunjukkan berapa besar koneksi antara neuron. Perubahan nilai bobot terjadi selama proses pembelajaran. Jika informasi yang diberikan tersampaikan maka nilai bobot akan bertambah begitu juga sebaliknya., Nilai bobot berubah secara dinamis hingga mencapai suatu nilai yang seimbang jika proses pembelajaran dilakukan dengan input berbeda. Sistem dianggap konvergen bila Input yang mengindikasikan bahwa nilai telah tercapai berhubungan dengan target output yang diharapkan. Proses pembelajaran Artificial Neural Network dibedakan menjadi dua yaitu:

- Terawasi (Supervised)

Satu pola input akan diberikan ke satu neuron pada lapisan input yang disebut dengan proses pembelajaran terawasi. Pada layer output-nya, pola ini direntangkan sepanjang jaringan sampai ke neuron. Untuk membangkitkan pola output yang akan dicocokkan dengan pola output target adalah layer output ini. Akan muncul error apabila perbedaan yang terjadi antara pola output hasil pembelajaran dengan pola target. Lakukan terus proses pembelajaran lagi sampai nilai error mencapai nilai yang diharapkan, jika nilai error masih cukup besar.

\section{- Tidak terawasi (Unsupervised)}

Proses pembelajaran tidak terawasi tidak diperlukan target output. Metode ini tidak dapat ditentukan hasil seperti yang diharapkan. range tertentu atau jaringan akan menentukan sendiri pasangan output dari input yang diberikan padanya, dengan dasar 
nilai kesesuaian dengan pola yang pernah diterima sebelumnya adalah proses pembelajaran nilai bobot.

\section{Metode Backpropagation}

Metode Backpropagation merupakan algoritma pembelajaran yang terawasi, biasanya untuk mengubah bobot yang terhubung dengan neuron pada lapisan tersembunyi (Hidden Layer) menggunakan perceptron dengan banyak lapisan. Dalam algoritma backpropagation, untuk menentukan nilai bobotnya arah mundur (backword) digunakan error ouput untuk mengubahnya. Pertama-tama kerjakan tahap perambatan maju (forword propagation) dalam error output ini. Artificial Neural Network Backpropagation terdiri atas satu atau lebih unit lapisan layer pemroses. Layer input yang berfungsi menerima input dari luar adalah unit layer paling bawah (awal). Layer hidden adalah layer atasnya. Layer output adalah layer yang paling atas. Keluaran setiap sel pada layer input terhubung dengan semua sel pada layer hidden dan keluarannya terhubung dengan semua sel pada layer ouput. Struktur Artificial Neural Network Multi-layer Perceptron dapat dilihat pada Gambar. 1.

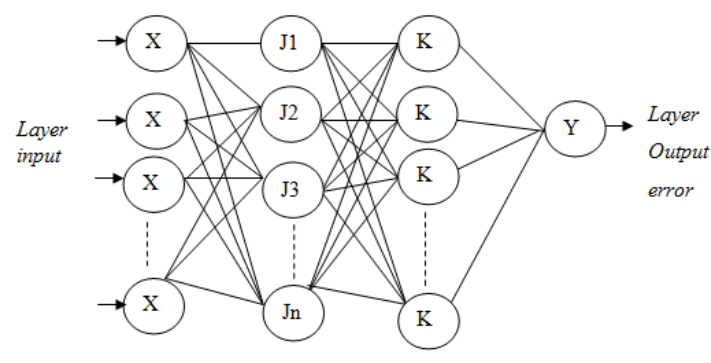

Laver Hidden

Gambar 1: Struktur Artificial Neural Network Backpropogation

\section{Metodologi}

Penelitian ini dilakukan di PT. PLN (Persero) Penyaluran dan Pusat Pengatur Beban Jawa Bali, Area Pelaksana Pemeliharaan (P3B JB APP) Bali Gardu Induk Kapal, Jl. Abianbase Kapal, Kecamatan Mengwi, Kabupaten Badung. Penelitian ini dimulai pada bulan Desember 2011. Data yang digunakan dalam penelitian ini adalah data sekunder yang diperoleh dari PT. PLN (Persero) Penyaluran dan Pusat Pengatur Beban Jawa Bali, Area Pelaksana Pemeliharaan (P3B JB APP) Bali Gardu Induk Kapal. Alur analisis dari penelitian ini adalah sebagai berikut:

1. Pengumpulan data-data yang berkaitan dengan penelitian yaitu data impedansi penghantar sistem Bali, data penghantar $150 \mathrm{kV}$ sub sistem Bali, data setting-an distance relay di wilayah sub-region Bali, single line sub-region Bali, dan load of flow sub-sistem Bali.

2. Membuat simulasi gangguan arus hubung singkat menggunakan ETAP Power Station dengan memasukan data nilai impedansi penghantar sistem GI Kapal-GI Pemecutan Kelod, transformator, busbar, pembangkit, dan data beban sub sistem Bali, sementara untuk daerah gangguan ditentukan bus bar $150 \mathrm{kV}$.

3. Analisa arsitektur jaringan ANN dengan metode backpropagation yang akan digunakan untuk menentukan settingan rele jarak SUTT $150 \mathrm{kV}$ GI Kapal-Pemecutan Kelod, dengan membuat pola input dengan 6 sel yang terdiri dari arus gangguan 3 phasa, arus gangguan 2 phasa, arus gangguan 2 phasa ke tanah, arus gangguan 1 phasa ke tanah, $\mathrm{I}_{\text {nominal }}$ Transformator 1732 kVA, dan ratio CT yang bernilai 800/1 A, 1 lapisan hidden layer dengan 140 sel, dan output dengan 3 sel yaitu settingan rele jarak $\mathrm{R}, \mathrm{X}, \mathrm{Z}$.

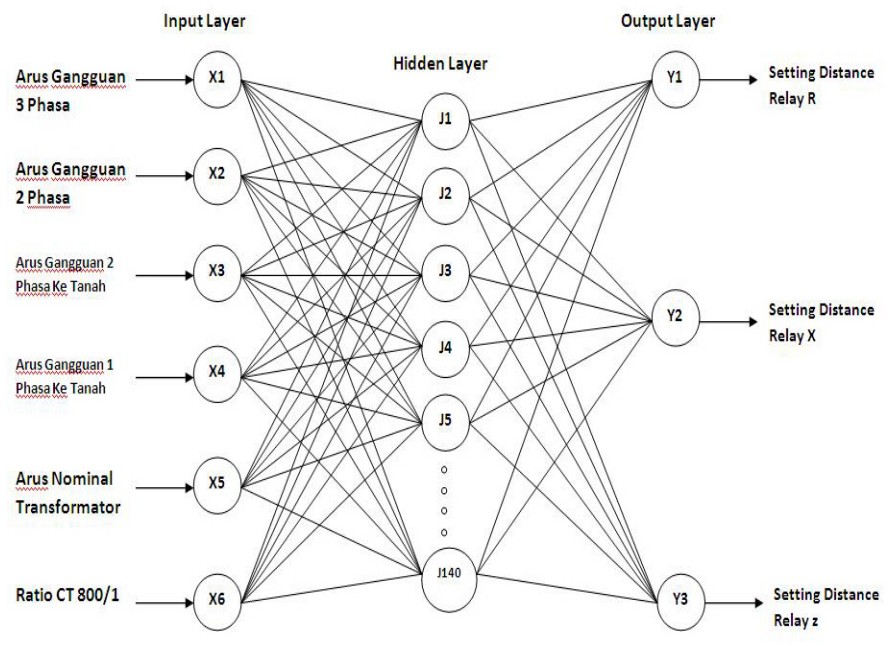

Gambar 2: Struktur ANN Backpropagation yang Digunakan Untuk Menentukan Setting Rele Jarak SUTT 150 kV GI Kapal-Pemecutan Kelod

4. Hasil akhir yang didapatkan akan dibandingkan dengan data nilai setting rele jarak pada sistem jaringan SUTT 150 kV GI Kapal-GI Pemecutan Kelod. Untuk mengetahui apakah metode ANN dapat menjalankan fungsinya dengan baik saat digunakan untuk menentukan settingan rele jarak.

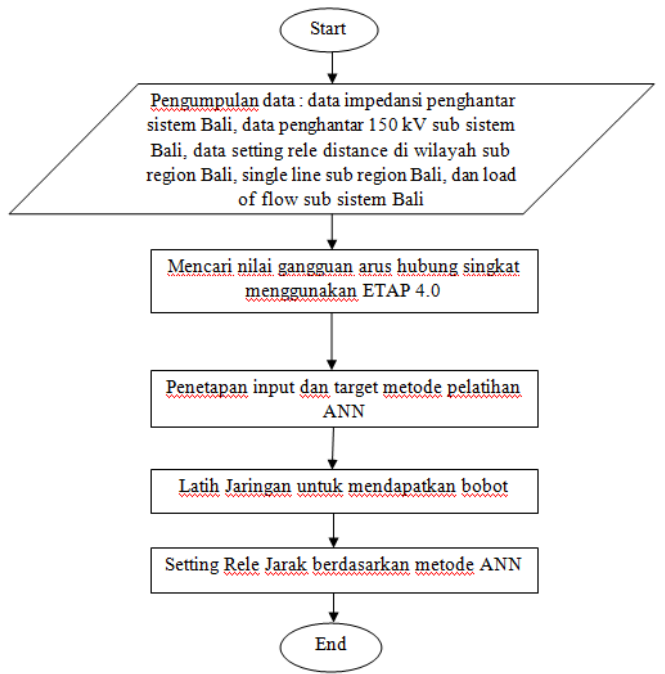

Gambar 3: Alur Analisis

\section{HaSil Dan Pembahasan}

A. Analisis Hubung Singkat Pada Sistem Jaringan SUTT 150 kV GI Kapal-GI Pemecutan Kelod

Analisis hubung singkat dilakukan untuk mencari nilai arus gangguan hubung singkat yang terjadi pada daerah pengaman saluran penghantar pada SUTT 150 kV GI KapalGI pemecutan Kelod karena berpengaruh terhadap seting proteksi rele jarak.. Langkah awal yang dilakukan untuk 
menganalisa besarnya arus hubung singkat adalah dengan menggambar secara kesuluruhan diagram segaris mulai dari sumber supply daya, busbar, transformator, dan beban. Masukkan data yang diperlukan untuk running program yang terdapat pada halaman lampiran.

\section{B. Gambar Single Line Diagram}

Gambar single line diagram untuk mencari nilai arus hubung singkat sebagai berikut:

1. Gambar single line diagram dengan gangguan di saluran transmisi $150 \mathrm{kV}$ GI Kapal-GI Pemecutan Kelod ditampilkan pada Gambar 4 dibawah ini :

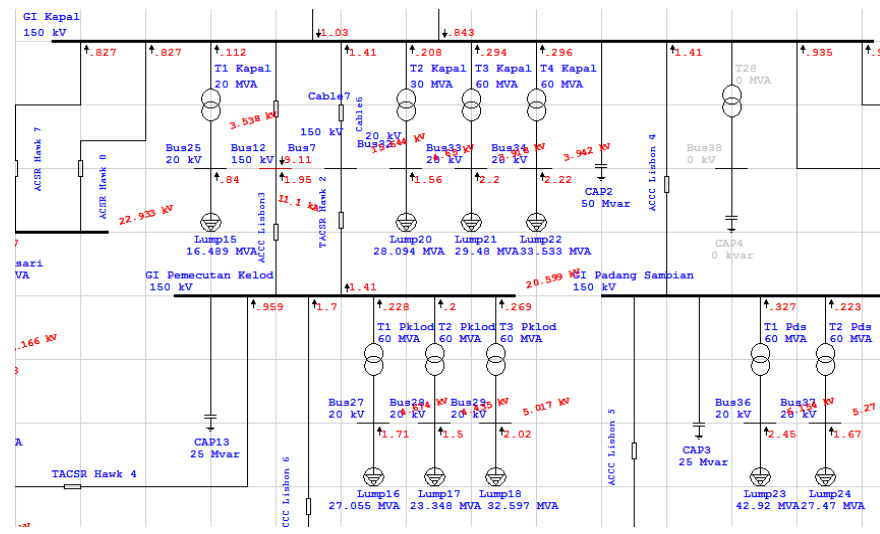

Gambar.4: Single Line Diagram Sistem Ketenagalistrikan 150 kV GI Kapal GI Pemecutan Kelod

2. Gambar single line diagram dengan gangguan di saluran transmisi $150 \mathrm{kV}$ GI Pemecutan Kelod-GI Pesanggaran ditampilkan pada Gambar 5 dibawah ini :

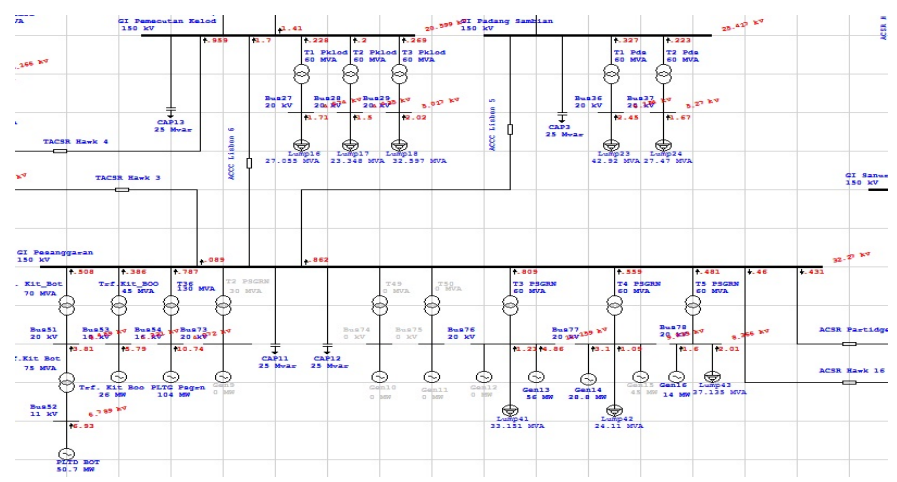

Gambar 5: Single Line Diagram Sistem Ketenagalistrikan 150 Kv GI Pemecutan Kelod- GI Pesanggaran

3. Gambar single line diagram dengan gangguan di saluran transmisi $150 \mathrm{kV}$ GI Pesanggaran-GI Padang Sambian ditampilkan pada Gambar 6.

Masukan variasi beban yang didapatkan dari pihak PT. PLN (Persero) UBS P3B Sub Region Bali Gardu Induk Kapal ke dalam Single Line Diagram sebanyak 52 variasi terhitung dari tanggal 1 sampai 27 desember 2011 pada pukul 11.00 dan 20.00. (PT. PLN (Persero) UBS P3B Sub Region Bali Gardu Induk Kapal

C. Menentukan Nilai Seting Rele Jarak Menggunakan Metode Artificial Neural Network (ANN)
Metode Artificial Neural Network dalam pencarian nilai seting rele jarak dalam penelitian ini dapat dijelaskan sebagai berikut:

1. Arsitektur Jaringan yang Digunakan Untuk Pencarian Setting Rele Jarak

Arsitektur jaringan yang digunakan oleh algoritma backpropagation pada penelitian ini adalah jaringan feedforward dengan banyak lapisan (multilayer), yang menggunakan satu lapisan masukan (input layer), satu lapisan dalam (hidden layer) dan satu lapisan keluaran (output layer). Suatu jaringan feedforward dibangun menggunakan intruksi newff. Lapisan masukan (input layer) terdiri dari 6 sel yang merupakan arus gangguan ( arus gangguan 3 fasa), (arus gangguan 2 fasa), (arus gangguan 2 fasa ke tanah), dan ( arus gangguan 1 fasa ke tanah ), $\mathrm{I}_{\text {nominal }}$ Transformator $1732 \mathrm{kVA}$, dan ratio CT yang terpasang bernilai 800/1 A. Jumlah sample yang dilatih sebanyak 5 variasi yang merupakan data output target. Output target yang akan digunakan pada metode Artificial Neural Network adalah nilai seting rele jarak GI Kapal-GI Pemecutan Kelod 1 tahun terakhir yaitu data Pada tahun 2011. Fungsinya adalah untuk menguji ketepatan data yang ada dan meminimumkan nilai kesalahan serta mendekati nilai target yang sudah ditentukan.

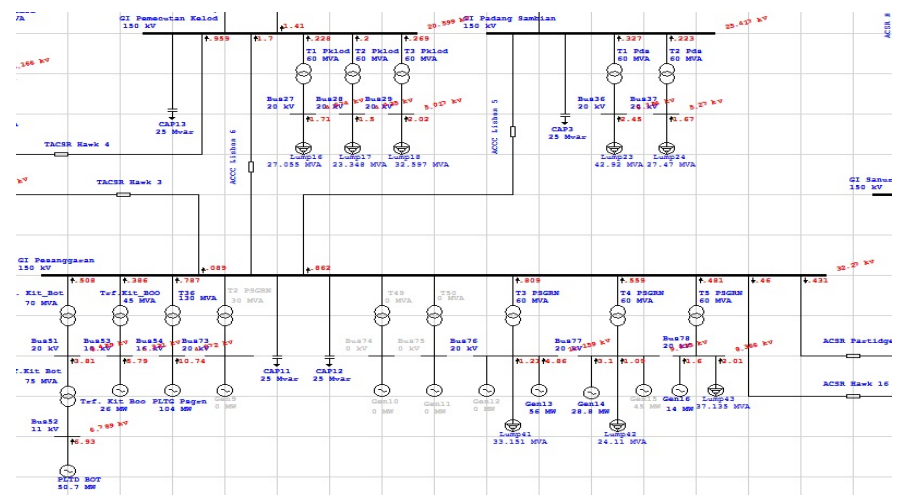

Gambar. 6: Single Line Diagram Sistem Ketenagalistrikan 150 kV GI Pesanggaran - GI Padang Sambian

Tabel 1: Nilai Seting Rele Jarak Gi Kapal-Gi Pemecutan Kelod

\begin{tabular}{|c|c|c|c|c|c|c|c|c|c|c|}
\hline \multirow{3}{*}{ No } & \multirow{3}{*}{ Tahun } & \multicolumn{4}{|c|}{ Seting Rele Jarak Kapal - Pemecutan Kelod $(\Omega)$} \\
\cline { 3 - 11 } & & \multicolumn{3}{|c|}{ Zona 1 } & \multicolumn{3}{c|}{ Zona 2 } & \multicolumn{3}{c|}{ Zona 3 } \\
\cline { 3 - 10 } & & $\mathrm{R}$ & $\mathrm{X}$ & $\mathrm{Z}$ & $\mathrm{R}$ & $\mathrm{X}$ & $\mathrm{Z}$ & $\mathrm{R}$ & $\mathrm{X}$ & $\mathrm{Z}$ \\
\hline 1 & 2011 & 0.977 & 2.684 & 2.684 & 1.341 & 3.684 & 3.92 & 2.107 & 5.789 & 6.16 \\
\hline
\end{tabular}

Jumlah lapisan dalam (hidden layer) adalah 1 lapisan ditentukan secara acak, karena belum ada ketentuan yang mengatur jumlah lapisan dalam dan jumlah sel dalam lapisan ini) dengan 140 sel (neuron). Jumlah sel pada lapisan keluaran (output layer) adalah 3 sel, yang merupakan vektor keluaran Artificial Neural Network, yaitu setting rele jarak. Artificial Neural Network memetakan suatu sistem 6 dimensi ke 3 dimensi.

\section{Menentukan Nilai Setting Rele Jarak}

Artificial Neural Network memiliki karakteristik secara umum yaitu, untuk menentukan seting rele jarak dalam penelitian ini terdiri dari dua mode, yaitu mode pelatihan (train) dan mode pengujian. Mode pelatihan (train) 
merupakan tahap penyesuaian bobot-bobot jaringan. Dalam penelitian ini, mode pelatihan (train) yang digunakan adalah trainrp yaitu pelatihan resilent backpropagation.

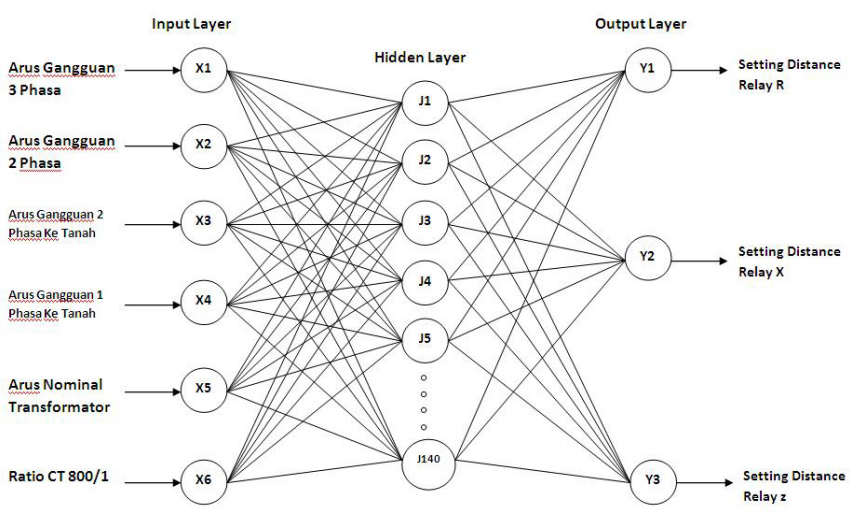

Gambar 7: Arsitektur ANN Backpropagation Untuk Menentukan Seting Rele Jarak Pada GI Kapal-GI Pemecutan Kelod

Pelatihan ini jaringan syaraf yang dibangun dengan struktur multilayer menggunakan fungsi aktivasi sigmoid. Fungsi aktivasi ini akan membawa input dengan range yang tak terbatas ke nilai output dengan range yang terbatas, yaitu antara 0 sampai 1. Karakteristik dari fungsi sigmoid adalah gradiennya akan mendekati nol, apabila input yang diberikan sangat banyak. Gradien yang mendekati nol ini berimplikasi pada rendahnya perubahan bobot. Bobot tidak cukup mengalami perubahan, maka algoritma akan sangat lambat untuk mendekati nilai optimumnya.

Resilent backpropagation berusaha untuk mengeliminasi besarnya efek turunan parsial dengan cara hanya menggunakan tanda turunannya saja dan mengabaikan besarnya nilai turunan. Besarnya perubahan setiap bobot akan ditentukan oleh suatu faktor yang diatur pada parameter delt_inc atau delt_dec. Gradien fungsi kinerja berubah tanda dari satu iterasi ke iterasi berikutnya, maka bobot akan berkurang sebesar delt_dec senilai 0,6. Gradien fungsi kinerja tidak berubah tanda dari satu iterasi ke iterasi berikutnya, maka bobot akan bertambah sebesar delt_inc senilai 1,5. Gradien fungsi kinerja sama dengan nol, maka perubahan bobot sama dengan perubahan bobot sebelumnya. Awal iterasi, besarnya perubahan bobot diinisialisasikan dengan parameter delta0 senilai 0,05 . Besarnya perubahan tidak boleh melebihi batas maksimum yang terdapat pada parameter deltamax senilai 50, apabila perubahan bobot melebihi maksimum perubahan bobot maka perubahan bobot akan diset sama dengan maksimum perubahan bobot.

Menentukan nilai parameter epochs, goal, dan learning rate yang akan digunakan untuk melatih jaringan dalam program. Pada mode pelatihan menggunakan parameter goal target $0,00001\left(10^{-5}\right)$, learning rate 0,01 dan jumlah epoch maksimum sebesar 50000 epoch. Latihan jaringan yang dilakukan akan berhenti bila maksimum epochs telah tercapai atau hasil pelatihan mencapai goal, dan telah mencapai nilai konvergensinya. Jumlah sel (neuron) lapisan dalam yang digunakan adalah 140 sel. Jumlah sel lapisan dalam tersebut ditentukan berdasarkan hasil coba-coba dan salah. Jumlah sel diubah terus hingga mendapatkan hasil dengan selisih antara target dan nilai rata - rata seting proteksi data output target Alfian Budy Hadianto: studi perhitungan relay jarak ........... (tabel 4.4) pada mode pelatihan sekecil mungkin. Jaringan yang sudah dilatih memiliki bobot (weight) baru yang nantinya akan digunakan sebagai bobot pada proses pencarian setting rele jarak. Data yang dipakai untuk mode pelatihan (train) adalah data pada Tabel 4 dimana terdapat 1 data dari tahun 2011. Input-an pada mode ini adalah nilai arus gannguan 3 phasa, arus gangguan 2 phasa, arus gangguan 2 phasa ke tanah, arus gangguan 1 phasa ke tanah, $\mathrm{I}_{\text {nominal }}$ transformator $1732 \mathrm{kVA}$, dan ratio CT yang terpasang senilai 800/1 A. Mode pengujian digunakan nilai rata-rata arus gangguan yang terjadi serta nilai arus nominal transformator dan ratio CT terpasang. Nilai target yang didapatkan berupa seting Rele Jarak $R$, seting Rele Jarak $X$, dan seting Rele Jarak $Z$, maka hasil dari mode pengujaian ANN ini akan dibandingkan dengan nilai seting Rele Jarak GI Kapal-GI Pemecutan Kelod pada tahun 2011.

\section{Hasil Pelatihan Artificial Neural Network ( ANN)}

Pelatihan ANN memakai struktur seperti pada Gambar 7. Dengan memasukkan 13 hari untuk menghasilkan nilai setting relay pada tahun 2011. Hasil pelatihan Artificial Neural Network zona 1, zona 2 dan zona 3 ditunjukkan pada Gambar. 8, 9, 10 berikut:

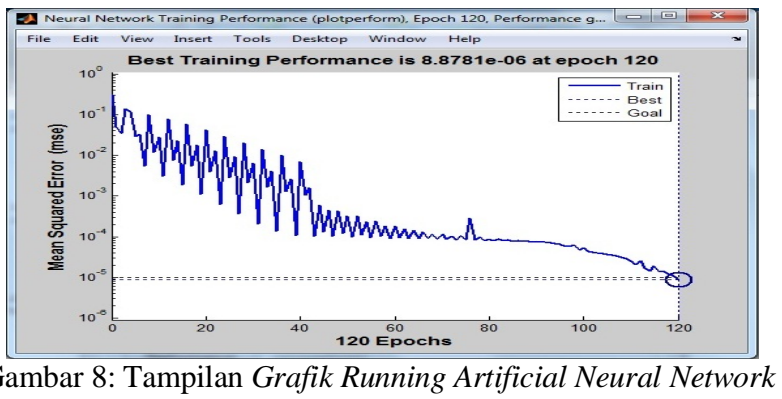
Zona1

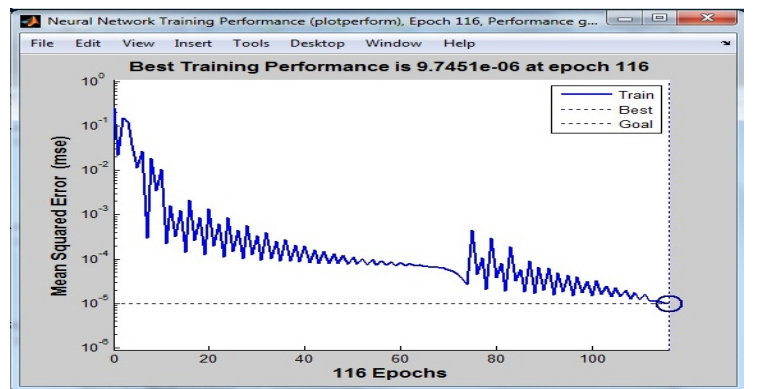

Gambar 9: Tampilan Grafik Running Artificial Neural Network Zona 2

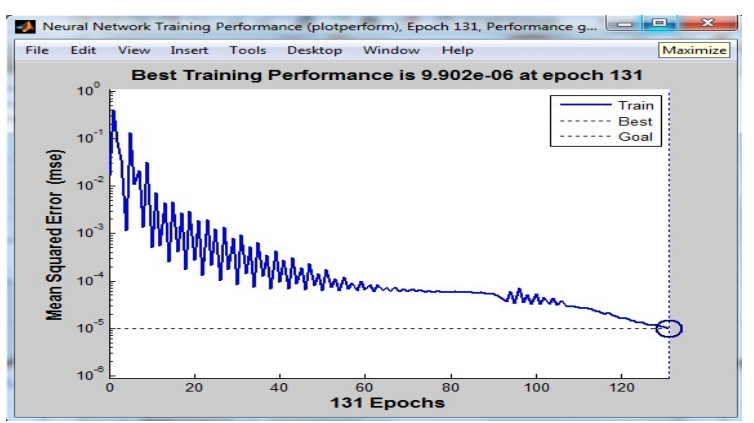

Gambar 10: Tampilan Grafik Running Artificial Neural Network Zona 3

p-ISSN:1693 - 2951; e-ISSN: 2503-2372 
4. Hasil Pengujian Menggunakan Artificial Neural Network

Menggunakan Data Latih Eksekusi program didapatkan hasil running setting rele jarak sebagai berikut:

Tabel. 2 : Hasil Pengujian Dengan Memakai Data Latih Artificial Neural Network (Ann)

\begin{tabular}{|l|c|c|c|c|c|c|c|c|c|}
\hline \multirow{2}{*}{ Data Latih } & \multicolumn{3}{|c|}{ Zone 1 } & \multicolumn{3}{c|}{ Zone 2 } & \multicolumn{3}{|c|}{ Zone 3 } \\
\cline { 2 - 10 } & $\mathrm{R}$ & $\mathrm{X}$ & $\mathrm{Z}$ & $\mathrm{R}$ & $\mathrm{X}$ & $\mathrm{Z}$ & $\mathrm{R}$ & $\mathrm{X}$ & $\mathrm{Z}$ \\
\hline \hline ANN hari 1 & 0.9911 & 2.6886 & 2.86 & 1.3313 & 2.6872 & 3.92 & 2.1251 & 5.7872 & 6.16 \\
\hline ANN hari 2 & 0.984 & 2.6877 & 2.86 & 1.3434 & 2.6871 & 3.92 & 2.0995 & 5.7861 & 6.16 \\
\hline ANN hari 3 & 0.9768 & 2.6872 & 2.86 & 1.3543 & 2.686 & 3.92 & 2.0808 & 5.7857 & 6.16 \\
\hline ANN hari 4 & 0.9624 & 2.6867 & 2.86 & 1.374 & 2.6854 & 3.92 & 2.0539 & 5.786 & 6.16 \\
\hline ANN hari 5 & 0.9811 & 2.6875 & 2.86 & 1.3478 & 2.6858 & 3.92 & 2.0915 & 5.7859 & 6.16 \\
\hline ANN hari 6 & 0.9824 & 2.6875 & 2.86 & 1.3458 & 2.6861 & 3.92 & 2.0948 & 5.786 & 6.16 \\
\hline ANN hari 7 & 0.9799 & 2.6873 & 2.86 & 1.3497 & 2.6867 & 3.92 & 2.0878 & 5.7858 & 6.16 \\
\hline ANN hari 8 & 0.9854 & 2.6878 & 2.86 & 1.3409 & 2.6874 & 3.92 & 2.1043 & 5.7863 & 6.16 \\
\hline ANN hari 9 & 0.9765 & 2.6871 & 2.86 & 1.3544 & 2.6873 & 3.92 & 2.0803 & 5.7857 & 6.16 \\
\hline ANN hari 10 & 0.958 & 2.6867 & 2.86 & 1.3795 & 2.686 & 3.92 & 2.0478 & 5.7861 & 6.16 \\
\hline ANN hari 11 & 0.9765 & 2.6871 & 2.86 & 1.3544 & 2.6858 & 3.92 & 2.08 & 5.7857 & 6.16 \\
\hline ANN hari 12 & 0.984 & 2.6877 & 2.86 & 1.3434 & 2.6863 & 3.92 & 2.1251 & 5.7872 & 6.16 \\
\hline ANN hari 13 & 0.9844 & 2.6877 & 2.86 & 1.3428 & 2.687 & 3.92 & 2.0995 & 5.7861 & 6.16 \\
\hline Data Existing 2011 & 0.977 & 2.684 & 2.684 & 1.341 & 3.684 & 3.92 & 2.107 & 5.789 & 6.16 \\
\hline
\end{tabular}

Tabel. 3 : Hasil Pengujian Dengan Memakai Data Uji Artificial Neural Network (Ann)

\begin{tabular}{|c|c|c|c|c|c|c|c|c|c|}
\hline \multirow{2}{*}{ Data Uii } & \multicolumn{3}{|c|}{ Zone 1} & \multicolumn{3}{|c|}{ Zone 2} & \multicolumn{3}{|c|}{ Zone 3} \\
\hline & $\mathrm{R}$ & $\mathrm{x}$ & $z$ & $\mathrm{R}$ & $\mathrm{x}$ & $z$ & $\mathrm{R}$ & $\mathrm{x}$ & $z$ \\
\hline ANN hari 14 & 1.0044 & 2.6872 & 2.86 & 1.3335 & 3.6798 & 3.92 & 2.1087 & 5.7891 & 6.16 \\
\hline ANN han 15 & 1.0037 & 2.6871 & 2.86 & 1.3346 & 3.6899 & 3.92 & 2.1008 & 5.7862 & 6.16 \\
\hline ANN hari 16 & 0.9925 & 2.686 & 2.86 & 1.3514 & 3.697 & 3.92 & 2.1214 & 5.7891 & 6.16 \\
\hline ANN han 17 & 0.9717 & 2.6854 & 2.86 & 1.3778 & 3.7066 & 3.92 & 2.1185 & 5.7889 & 6.16 \\
\hline ANN hari 18 & 0.9882 & 2.6858 & 2.86 & 1.3569 & 3.693 & 3.92 & 2.0852 & 5.7879 & 6.16 \\
\hline ANN hari 19 & 0.9933 & 2.6861 & 2.86 & 1.3502 & 3.6917 & 3.92 & 2.0492 & 5.7883 & 6.16 \\
\hline ANN hari 20 & 0.9999 & 2.6867 & 2.86 & 1.3404 & 3.6943 & 3.92 & 2.0761 & 5.7878 & 6.16 \\
\hline ANN han 21 & 1.0058 & 2.6874 & 2.86 & 1.3307 & 3.6881 & 3.92 & 2.0874 & 5.788 & 6.16 \\
\hline ANN hari 22 & 1.0046 & 2.6873 & 2.86 & 1.3328 & 3.6971 & 3.92 & 2.1062 & 5.7884 & 6.16 \\
\hline ANN hani 23 & 0.9915 & 2.686 & 2.86 & 1.3525 & 3.7087 & 3.92 & 2.1275 & 5.7894 & 6.16 \\
\hline ANN har 24 & 0.9871 & 2.6858 & 2.86 & 1.3584 & 3.6972 & 3.92 & 2.123 & 5.7891 & 6.16 \\
\hline ANN hari 25 & 0.9963 & 2.6863 & 2.86 & 1.3456 & 3.6899 & 3.92 & 2.0835 & 5.7879 & 6.16 \\
\hline ANN hari 26 & 1.0034 & 2.687 & 2.86 & 1.3349 & 3.6895 & 3.92 & 2.0743 & 5.7879 & 6.16 \\
\hline Data Existing 2011 & 0.977 & 2.684 & 2.684 & 1.341 & 3.684 & 3.92 & 2.107 & 5.789 & 6.16 \\
\hline
\end{tabular}

\section{Persentase Perbedaan} berikut :

Persentase perbedaan dapat dihitung dengan rumus sebagai

$$
\%=\left[\frac{\text { Nilai ANN }- \text { Nilai Target }}{\text { Nilai Target }}\right] \times 100 \%
$$

Catatan: Untuk pengurangan nilai ANN dengan nilai target yang bernilai negatif (-), akan dijadikan positif.

Perhitungan persentase perbedaannya sebagai berikut :

1. zona 1 :

$$
\begin{aligned}
& \% \mathrm{R}=\left[\frac{\text { Nilai ANN }- \text { Nilai Target }}{\text { Nilai Target }}\right] \times 100 \% \\
& \% \mathrm{R}=\left[\frac{0.9911-0.977}{0.977}\right] \times 100 \% \\
& \% \mathrm{R}=\frac{0.0141}{0.977} \times 100 \% \\
& \% \mathrm{R}=0,014 \% \\
& \% \mathrm{X}=\left[\frac{\text { Nilai ANN- Nilai Target }}{\text { Nilai Target }}\right] \times 100 \% \\
& \% \mathrm{X}=\left[\frac{2.6886-2.684}{2.684}\right] \times 100 \% \\
& \% \mathrm{X}=\frac{0.0046}{2.684} \times 100 \% \\
& \% \mathrm{X}=0.002 \% \\
& \% \mathrm{Z}=\left[\frac{\mathrm{Nilai} \text { ANN }- \text { Nilai Target }}{\text { Nilai Target }}\right] \times 100 \% \\
& \% \mathrm{Z}=\left[\frac{2.86-2.86}{2.86}\right] \times 100 \% 2.86 \\
& \% \mathrm{Z}=\frac{0}{2.86} \times 100 \% \\
& \% \mathrm{Z}=0 \%
\end{aligned}
$$

2. zona 2 :

$$
\begin{aligned}
\% \mathrm{R} & =\left[\frac{\text { Nilai ANN }- \text { Nilai Target }}{\text { Nilai Target }}\right] \times 100 \% \\
\% \mathrm{R} & =\left[\frac{1.3313-1.341}{1.341}\right] \times 100 \% \\
\% \mathrm{R} & =\frac{0.097}{1.341} \times 100 \% \\
\% \mathrm{R} & =0.0072 \%
\end{aligned}
$$

$\% \mathrm{X}=\left[\frac{\text { Nilai ANN- Nilai Target }}{\text { Nilai Target }}\right] \times 100 \%$

$\% \mathrm{X}=\left[\frac{(3.6798-3.684)}{3.684}\right] \times 100 \%$

$\% \mathrm{X}=\frac{0.0042}{3.684} \times 100 \%$

$\% \mathrm{X}=0.01 \%$

$\% \mathrm{Z}=\left[\frac{\text { Nilai ANN }- \text { Nilai Target }}{\text { Nilai Target }}\right] \times 100 \%$

$\% Z=\left[\frac{3.92-3.92}{3.920}\right] \times 100 \%$

$\% \mathrm{Z}=\frac{0}{3.92} \times 100 \%$

$\% \mathrm{Z}=0 \%$

3. Zone 3 :

$$
\begin{aligned}
& \% \mathrm{R}=\left[\frac{\text { Nilai ANN- Nilai Target }}{\text { Nilai Target }}\right] \times 100 \% \\
& \% \mathrm{R}=\frac{(2.1251-2.107)}{2.107} \times 100 \% \\
& \% \mathrm{R}=\frac{0.181}{2.107} \times 100 \% \\
& \% \mathrm{R}=19.2 \% \\
& \% \mathrm{X}==\left[\frac{\text { Nilai ANN- Nilai Target }}{\text { Nilai Target }}\right] \times 100 \% \\
& \% \mathrm{X}=\left[\frac{2.0995-5.789}{5.789}\right] \times 100 \% \\
& \% \mathrm{X}=\frac{0.036}{5.789} \times 100 \% \\
& \% \mathrm{X}=7.1 \% \\
& \% \mathrm{Z}==\left[\frac{\text { Nilai ANN- Nilai Target }}{\text { Nilai Target }}\right] \times 100 \% \\
& \% \mathrm{Z}=\left[\frac{6.16-6.16}{6.16}\right] \times 100 \% \\
& \% \mathrm{Z}=\frac{0}{6.16} \times 100 \% \\
& \% \mathrm{Z}=0 \%
\end{aligned}
$$


Tabel. 4 : Persentase Perbedaan Zona 1

\begin{tabular}{|c|c|c|c|c|c|c|c|c|c|}
\hline & \multicolumn{3}{|c|}{ Hasil ANN } & \multicolumn{3}{|c|}{ Data 2011} & \multicolumn{3}{|c|}{ Persentase perbedaan } \\
\hline & $\mathrm{R}$ & $\mathrm{x}$ & $\mathrm{Z}$ & $\mathrm{R}$ & $\mathrm{x}$ & Z & $\mathrm{R}$ & $\mathrm{x}$ & $\mathrm{Z}$ \\
\hline hari 1 & 0.9911 & 2.6886 & 2.86 & 0.977 & 2.684 & 2.86 & 0.0144 & 0.0017 & 0.0000 \\
\hline hari 2 & 0.984 & 2.6877 & 2.86 & 0.977 & 2.684 & 2.86 & 0.0072 & 0.0014 & 0.0000 \\
\hline hari 3 & 0.9768 & 2.6872 & 2.86 & 0.977 & 2.684 & 2.86 & -0.0002 & 0.0012 & 0.0000 \\
\hline hari 4 & 0.9624 & 2.6867 & 2.86 & 0.977 & 2.684 & 2.86 & -0.0149 & 0.0010 & 0.0000 \\
\hline hari 5 & 0.9811 & 2.6875 & 2.86 & 0.977 & 2.684 & 2.86 & 0.0042 & 0.0013 & 0.0000 \\
\hline hari 6 & 0.9824 & 2.6875 & 2.86 & 0.977 & 2.684 & 2.86 & 0.0055 & 0.0013 & 0.0000 \\
\hline hari 7 & 0.9799 & 2.6873 & 2.86 & 0.977 & 2.684 & 2.86 & 0.0030 & 0.0012 & 0.0000 \\
\hline hari 8 & 0.9854 & 2.6878 & 2.86 & 0.977 & 2.684 & 2.86 & 0.0086 & 0.0014 & 0.0000 \\
\hline hari 9 & 0.9765 & 2.6871 & 2.86 & 0.977 & 2.684 & 2.86 & -0.0005 & 0.0012 & 0.0000 \\
\hline hari 10 & 0.958 & 2.6867 & 2.86 & 0.977 & 2.684 & 2.86 & -0.0194 & 0.0010 & 0.0000 \\
\hline hari 11 & 0.9765 & 2.6871 & 2.86 & 0.977 & 2.684 & 2.86 & -0.0005 & 0.0012 & 0.0000 \\
\hline hari 12 & 0.984 & 2.6877 & 2.86 & 0.977 & 2.684 & 2.86 & 0.0072 & 0.0014 & 0.0000 \\
\hline hari 13 & 0.9844 & 2.6877 & 2.86 & 0.977 & 2.684 & 2.86 & 0.0076 & 0.0014 & 0.0000 \\
\hline hari 14 & 1.0044 & 2.6872 & 2.86 & 0.977 & 2.684 & 2.86 & 0.0280 & 0.0012 & 0.0 \\
\hline hari 15 & 1.0037 & 2.6871 & 2.86 & 0.977 & 2.684 & 2.86 & 0.0273 & 0.0012 & 0.0000 \\
\hline hari 16 & 0.9925 & 2.686 & 2.86 & 0.977 & 2.684 & 2.8 & 0.0159 & 0.0007 & 0. \\
\hline hari 17 & 0.9717 & 2.6854 & 2.86 & 0.977 & 2.684 & 2.8 & -0.0054 & 0.0005 & 0.0 \\
\hline hari 18 & 0.9882 & 2.6858 & 2.86 & 0.977 & 2.68 & 2.8 & 0.0115 & 0.0007 & 0.0000 \\
\hline hari 19 & 0.9933 & 2.6861 & 2.86 & 0.977 & 2.684 & 2.8 & 0.0167 & 0.0008 & 0.0000 \\
\hline hari 20 & 0.9999 & 2.6867 & 2.86 & 0.977 & 2.68 & 2.8 & 0.0234 & 0.0010 & 0.0000 \\
\hline hari 21 & 1.0058 & 2.6874 & 2.86 & 0.977 & 2.684 & 2.86 & 0.0295 & 0.0013 & 0.0000 \\
\hline hari 22 & 1.0046 & 2.6873 & 2.86 & 0.977 & 2.684 & 2.86 & 0.0282 & 0.0012 & 0.0000 \\
\hline hari 23 & 0.9915 & 2.686 & 2.86 & 0.977 & 2.684 & 2.86 & 0.0148 & 0.0007 & 0.0000 \\
\hline hari 24 & 0.9871 & 2.6858 & 2.86 & 0.977 & 2.684 & 2.86 & 0.0103 & 0.0007 & 0.0000 \\
\hline hari 25 & 0.9963 & 2.6863 & 2.86 & 0.977 & 2.684 & 2.86 & 0.0198 & 0.0009 & 0.0000 \\
\hline hari 26 & 1.0034 & 2.687 & 2.86 & 0.977 & 2.684 & 2.86 & 0.0270 & 0.0011 & 0.0000 \\
\hline
\end{tabular}

Tabel. 5 : Persentase Perbedaan Zona 2

\begin{tabular}{|c|c|c|c|c|c|c|c|c|c|}
\hline & \multicolumn{3}{|c|}{ ANN } & \multicolumn{3}{|c|}{ ata 2011} & \multicolumn{3}{|c|}{ Persentase perbedaan } \\
\hline & $R$ & $\mathrm{X}$ & $\mathrm{Z}$ & $R$ & $\mathrm{x}$ & $\mathrm{Z}$ & 8 & $\mathrm{X}$ & $Z$ \\
\hline $\operatorname{ari} 1$ & 3 & & 92 & & & 16 & & & \\
\hline & & 99 & & & & & 37 & & \\
\hline & & 697 & & & 684 & 2.86 & 0 & & \\
\hline & 374 & 7066 & 3.92 & 977 & 2.684 & 2.86 & 0.4063 & .38 & 0.37 \\
\hline & 78 & 993 & 92 & & 684 & 86 & 3795 & - & \\
\hline $\operatorname{ari} 6$ & 458 & 6917 & 3.92 & 977 & 2.684 & 2.86 & 0.3775 & 0.3754 & 0.3706 \\
\hline & & 43 & .92 & & 07 & 2.86 & & & \\
\hline $2 \mathrm{yi}$ & 409 & .6881 & 3.92 & 977 & 2.684 & 2.86 & 0.3725 & 0.3741 & 0.3706 \\
\hline & 14 & 6971 & 3.92 & 977 & 2.684 & 2.86 & 3863 & 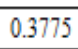 & \\
\hline & 2 & 7087 & 3.92 & 977 & 2.684 & 2.86 & 0.4120 & 0.3818 & 0.3706 \\
\hline 8 & 544 & 6972 & 3.92 & 97 & 2.684 & 2.86 & .3863 & 3775 & 0.3706 \\
\hline h & 434 & 6899 & 3.92 & 0.977 & 2.684 & 2.86 & 0.3750 & 0.3748 & 0.3706 \\
\hline 8 & 428 & 6895 & 3.92 & & 2.68 & 2.8 & .37 & . 37 & 0.3 \\
\hline b & 3335 & 6812 & 3.92 & 0.97 & 2.684 & 2.86 & .3649 & 0.37 & 0.3706 \\
\hline & & 823 & 3.92 & & 2.68 & 2.86 & 0.3660 & .3 & 0. \\
\hline & 14 & 6952 & 3.92 & 977 & 2.684 & 2.86 & 0.3832 & 0.3768 & 0.3706 \\
\hline hari 17 & 2710 & 7082 & 3.92 & & 2.684 & 2.86 & 0.41 & 0.3816 & 0.3706 \\
\hline 0 & 3569 & 6985 & 3.92 & 977 & 2.684 & 2.86 & 0.3888 & 0.3780 & 0.3706 \\
\hline & 2 & 6944 & 3.92 & & 2.684 & 2.86 & 0.3820 & 0.3765 & 0.3706 \\
\hline h & 1.3404 & 6873 & 3.92 & 977 & 2.684 & 2.86 & 0.3720 & 0.3738 & 0.3706 \\
\hline & & 7786 & 3.92 & & 2.684 & 2.86 & 0.3620 & 0.3706 & 0.3706 \\
\hline hari 22 & 3328 & 3.6805 & 3.92 & 977 & 2.684 & 2.86 & 0.3642 & 0.3713 & \begin{tabular}{|l|l}
0.3706 \\
\end{tabular} \\
\hline & 3525 & 6959 & 3.92 & & 2.684 & 2.86 & 0.3843 & 0.3770 & 0.3706 \\
\hline & 1.3584 & 3.6993 & 3.92 & 0.97 & 2.684 & 2.86 & 0.3904 & 0.3783 & 0.3706 \\
\hline & .3456 & 6912 & 3.92 & 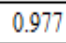 & 2.684 & 2.86 & 0.3773 & 0.3753 & 0.3706 \\
\hline nats 20 & 1.3349 & 3.6826 & 3. & & 2. & 2. & 0.3663 & 0 & 0.3 \\
\hline
\end{tabular}

Tabel 6 : Persentase Perbedaan Zona 3

\begin{tabular}{|c|c|c|c|c|c|c|c|c|c|}
\hline & \multicolumn{3}{|c|}{ Hasil ANN } & \multicolumn{3}{|c|}{ Data 2011} & \multicolumn{3}{|c|}{ Persentase perbedaan } \\
\hline & $\mathrm{R}$ & $\mathrm{x}$ & Z & $\mathrm{R}$ & $\mathrm{x}$ & $\mathrm{Z}$ & $\mathrm{R}$ & $\mathrm{x}$ & $\mathrm{Z}$ \\
\hline hari 1 & 2.1251 & 5.7872 & 6.16 & 0.977 & 2.684 & 2.86 & 1.1751 & 1.1562 & 1.1538 \\
\hline hari 2 & 2.0995 & 5.7861 & 6.16 & 0.977 & 2.684 & 2.86 & 1.1489 & 1.1558 & 1.1538 \\
\hline hari 3 & 2.0808 & 5.7857 & 6.16 & 0.977 & 2.684 & 2.86 & 1.1298 & 1.1556 & 1.1538 \\
\hline hari 4 & 2.0539 & 5.786 & 6.16 & 0.977 & 2.684 & 2.86 & 1.1023 & 1.1557 & 1.1538 \\
\hline hari 5 & 2.0915 & 5.7859 & 6.16 & 0.977 & 2.684 & 2.86 & 1.1407 & 1.1557 & 1.1538 \\
\hline hari 6 & 2.0948 & 5.786 & 6.16 & 0.977 & 2.684 & 2.86 & 1.1441 & 1.1557 & 1.1538 \\
\hline hari 7 & 2.0878 & 5.7858 & 6.16 & 0.977 & 2.684 & 2.86 & 1.1369 & 1.1557 & 1.1538 \\
\hline hari 8 & 2.1043 & 5.7863 & 6.16 & 0.977 & 2.684 & 2.86 & 1.1538 & 1.1558 & 1.1538 \\
\hline hari 9 & 2.0803 & 5.7857 & 6.16 & 0.977 & 2.684 & 2.86 & 1.1293 & 1.1556 & 1.1538 \\
\hline hari 10 & 2.0478 & 5.7861 & 6.16 & 0.977 & 2.684 & 2.86 & 1.0960 & 1.1558 & 1.1538 \\
\hline hari 11 & 2.08 & 5.7857 & 6.16 & 0.977 & 2.684 & 2.86 & 1.1290 & 1.1556 & 1.1538 \\
\hline hari 12 & 2.1087 & 5.7891 & 6.16 & 0.977 & 2.684 & 2.86 & 1.1583 & 1.1569 & 1.1538 \\
\hline hari 13 & 2.1008 & 5.7862 & 6.16 & 0.977 & 2.684 & 2.86 & 1.1503 & 1.1558 & 1.1538 \\
\hline hari 14 & 2.1214 & 5.7891 & 6.16 & 0.977 & 2.684 & 2.86 & 1.1713 & 1.1569 & 1.1538 \\
\hline hari 15 & 2.1185 & 5.7889 & 6.16 & 0.977 & 2.684 & 2.86 & 1.1684 & 1.1568 & 1.1538 \\
\hline hari 16 & 2.0852 & 5.7879 & 6.16 & 0.977 & 2.684 & 2.86 & 1.1343 & 1.1564 & 1.1538 \\
\hline hari 17 & 2.0492 & 5.7883 & 6.16 & 0.977 & 2.684 & 2.86 & 1.0974 & 1.1566 & 1.1538 \\
\hline hari 18 & 2.0761 & 5.7878 & 6.16 & 0.977 & 2.684 & 2.86 & 1.1250 & 1.1564 & 1.1538 \\
\hline hari 19 & 2.0874 & 5.788 & 6.16 & 0.977 & 2.684 & 2.86 & 1.1365 & 1.1565 & 1.1538 \\
\hline hari 20 & 2.1062 & 5.7884 & 6.16 & 0.977 & 2.684 & 2.86 & 1.1558 & 1.1566 & 1.1538 \\
\hline hari 21 & 2.1275 & 5.7894 & 6.16 & 0.977 & 2.684 & 2.86 & 1.1776 & 1.1570 & 1.1538 \\
\hline hari 22 & 2.123 & 5.7891 & 6.16 & 0.977 & 2.684 & 2.86 & 1.1730 & 1.1569 & 1.1538 \\
\hline hari 23 & 2.0835 & 5.7879 & 6.16 & 0.977 & 2.684 & 2.86 & 1.1325 & 1.1564 & 1.1538 \\
\hline hari 24 & 2.0743 & 5.7879 & 6.16 & 0.977 & 2.684 & 2.86 & 1.1231 & 1.1564 & 1.1538 \\
\hline hari 25 & 2.096 & 5.7881 & 6.16 & 0.977 & 2.684 & 2.86 & 1.1453 & 1.1565 & 1.1538 \\
\hline hari 26 & 2.1178 & 5.7889 & 6.16 & 0.977 & 2.684 & 2.86 & 1.1677 & 1.1568 & 1.1538 \\
\hline
\end{tabular}

Tabel. 6 dapat dilihat bahwa setting rele jarak yang didapatkan oleh proses ANN tidak terlampau jauh dengan nilai seting rele jarak GI Kapal-GI Pemecutan Kelod pada tahun 2011. Perbedaan itu dikarenakan nilai hubung singkat yang selalu berubah-ubah. Perbandingan tersebut membuktikan dengan mengukur nilai hubung singkat pada saluran transmisi SUTT $150 \mathrm{kV}$ antar gardu induk, setting rele jarak dapat dicari dengan menggunakan metode Artificial Neural Network. Pada Tabel 7, 8 dan 9 dapat dilihat persentase perbedaan dari zona 1, zona 2, zona 3 .Persentase perbedaan tersebut membuktikan bahwa proses setting rele jarak dengan metode Artificial Neural Network sudah berhasil

\section{KESIMPULAN}

Berdasarkan pembahasan yang telah dilakukan, maka dapat disimpulkan sebagai Berikut:

1. Persentase perbedaannya yaitu, zona 1 : $(\mathrm{R}=0,0144 \%$, $\mathrm{X}=0.0017 \%, \quad \mathrm{Z}=0.000 \%)$, zona $2: \quad(\mathrm{R}=0.3626 \%$, $X=0.3170 \%, \quad Z=0.3706 \%), \quad$ zona $3: \quad(R=1.1751 \%$, $\mathrm{X}=1.1562 \%, \quad \mathrm{Z}=1.1538 \%$ ) relatif kecil. Persentase Perbedaan tersebut membuktikan bahwa proses pencarian seting rele jarak pada GI Kapal-GI Pemecutan Kelod dengan metode Artificial Neural Network sudah berhasil.

2. Nilai seting rele jarak yang didapat dari proses Artificial Neural Network, ada yang lebih besar dan ada yang lebih kecil dari target yang ditentukan. Perbedaan ini tidak berpengaruh pada nilai seting rele jarak sesuai zona yang diamankan, karena penentuan nilai seting rele jarak sudah memiliki metodenya masing-masing serta sudah membuat simulasi gangguan sesuai letak daerah gangguan yang sudah ditentukan. 


\section{REFERENSI}

[1] Hidayatulloh,dkk. Analisa Gangguan Hubung Singkat Pada Jaringan SUTT 150 kV Jalur Kebasen - Balapulang - Bumiayu Menggunakan Program ETAP. 2012.

[2] Syafar, "Studi Keandalan Distance Relay Jaringan 150 kV GI Tello GI Pare - Pare," Jurnal Media Elektrik, vol. 5, Des. 2010,

[3] Permana. Studi Koordinasi Rele Proteksi Pada Sistem Kelistrikan PT BOC GASES Gresik Jawa Timur. 2010

[4] C. N. H. Tobing, "Rele Jarak Sebagai Proteksi Saluran Transmisi”Depok. Departemen Elektro Fakultas Teknik Universitas Indonesia. 2008.

[5] Samuel, dkk, "Koordinasi Setting Rele Jarak Pada Transmisi $150 \mathrm{kV}$ PLTU 2 SULUT 2 x 25 MW. 2012," Jurnal Teknik Elektro-FT UNSRAT. (tidak ada vol, no dan tahun)

[6] Anindita. Mutual Induktansi Kawat Hantar Listrik. 2013

[7] H. Sujatmiko, "Analisis Kerugian Daya Pada Saluran Transmisi Tegangan Ekstra Tinggi 500 kV Di PT PLN (Persero) Penyaluran \& Pusat Pengaturan Beban (P3B) Jawa Bali Regional Jawa Tengah \& DIY Unit Pelayanan Transmisi Semarang. 2009," Jurnal Teknik Elektro, vol. 1, Jan. 2009.

[8] E. Hawary, ME. Electrical Energy Systems. New York: Dalhousie University. 2000. 